\title{
The Influence Of Brand Image And Brand Experience On Brand Loyalty On Brizzi Card Users At BRI Unit Sentra Bisnis Driyorejo
}

\author{
Fuad Farhan dan Firman Aditya \\ Program Studi Manajemen, Fakultas Ekonomi Dan Bisnis \\ Universitas Narotama Surabaya \\ Email author: firman.aditya@narotama.ac.id
}

\begin{abstract}
Technology is getting more sophisticated, all daily activities are getting easier, including in terms of transactions. Now, the so-called Brizzi Card has become popular, which is a payment instrument with the value of money stored electronically on a server or card. This Brizzi card can then be used for payment transactions on the internet and merchants who have collaborated with the Brizzi card issuing bank. Became popular because Brizzi has been intensively used to transact online and offline stores. Public facilities have introduced the Brizzi Card as payment for tolls, commuter line, trans Jakarta, parking, and many more. This research was conducted to know and analyze the effect of brand image and brand experience on brand loyalty by using multiple linear regression analysis models. The sample used in this study were 100 respondents who were owners or users of the BRIZZI card at the Driorejo BRI Business Center Unit. The results showed that all research variables consisting of brand image and brand experience had a significant effect on the variable brand loyalty. This is proven empirically from the SPSS calculation which results in the calculated F value> F table, namely 16,156> 3.09 or by looking at the significant level of $0.000<0.05$. The results also show that the brand image variable has a significant effect on brand loyalty. This is proven empirically from the SPSS calculation which results in the value of $t$ count $>t$ table, namely $5.055>1.661$ or by looking at the significant level of $0.000<0.05$. Meanwhile, brand experience has no significant effect on brand loyalty. This is proven empirically from the SPSS calculation which results in the value of $t$ count $<\mathrm{t}$ table which is $1.086<1.661$ or by looking at the significant level of $0.280>0.05$.
\end{abstract}

\section{Keyword:}

Brand Image, Brand Experience, Brand Loyalty

\section{Pendahuluan \\ 1.1.Latar Belakang}

Produk jasa keuangan sekarang ini telah banyak beredar di pasar, mulai dari tabungan deposito, rekening giro, kartu kredit dan kartu debit. Perkembangan dalam industry jasa keuangan tidak berhenti sampai disitu, sekarang mulai banyak produk jasa keuangan yang disebut sebagai $e$-money. Dengan era $e$-money ini, persaingan antar perbankan menjadi semakin ketat dan kompetitif, dimana masing-masing perbankan akan berusaha memberikan layanan produk yang berbeda antara perbankan satu dengan perbankan lainnya. Salah satu diantara perbankan nasional yang memiliki produk e-money adalah Bank Rakyat Indonesia (BRI) dengan produk andalannnya BRI Flazz atau bisa disebut juga BRIZZI. BRIZZI adalah salah satu jenis produk $e$-money yang dikeluarkan oleh Bank BRI sebagai pengganti uang tunai untuk melakukan pembayaran.

Produk ini seperti produk e-money milik Bank lain, akan tetapi untuk mempertahakan citra merek dari produk ini Bank BRI perlu menjelaskan adanya kelebihan BRIZZI dibandingkan produk flash milik Bank lain. Dengan adanya kelebihan dari BRIZZI, Bank BRI masih perlu berinteraksi dengan nasabah lewat media sosial seperti chat online dari BRI Contact Center yang disediakan khusus dalam website resmi PT. Bank Rakyat Indonesia tersebut (www.bri.co.id). Adanya interaksi dalam media sosial tersebut, Bank BRI juga bisa melihat respon nasabah dalam menikmati BRIZZI atau bisa disebut brand experience. Melalui media ini, BRI juga dapat mengevaluasi kritik dan saran yang disampaikan oleh nasabah ataupun konsumen pengguna BRIZZI. Manakala dari citra merek, intraksi media sosial dan juga respon masyarakat terhadap merek BRIZZI ini nantinya dapat berdampak pada brand loyalty. Tujuan daripada penelitian ini adalah untuk menganalisis pengaruh brand image dan brand experience terhadap brand loyalty. 


\subsection{Kajian Pustaka \\ 1.2.1. Brand Image}

Merek (brand) dapat memberikan manfaat yang besar bagi produsen maupun konsumen. Merek juga mampu menambah nilai bagi konsumen. Citra dan keyakinan atas produk tertentu yang mempunyai reputasi baik, pada umumnya akan menyebabkan konsumen ingin terasosiasikan dan membelinya, sehingga konsumen tidak segan membayar mahal untuk mendapatkan produk dengan merek tertentu. Konsumen bersedia untuk membayar lebih tinggi atas suatu produk karena melekat merek yang merupakan jaminan konsistensi kualitas dan nilai tertentu yang diyakini terkandung didalamnya, tanpa adanya merek konsumen menjadi kurang merasa aman dari kemungkinan buruk diluar harapan (Sundjoto dan Hadi, 2012).

Citra merek menjadi hal yang sangat penting diperhatikan perusahaan, karena melalui citra merek yang baik, maka dapat menimbulkan nilai emosional pada diri konsumen, dan akan timbul perasaan positif (positive feeling) pada saat konsumen membeli atau menggunakan suatu merek.

Brand image memiliki tiga komponen, yaitu: karakteristik fisik produk suatu merek yang dikenali konsumen, kekuatan merek yang mampu menimbulkan manfaat yang disukai maupun tidak disukai berdasarkan skala penilaian konsumen, dan yang terakhir adalah kekuatan konsumen mengenai keyakinanya menentukan secara akurat kualitas suatu merek.

Low and Lamb (2000) mengemukakan indikator dari brand image antara lain:

1. Friendly / unfriendly: kemudahan dikenali oleh konsumen

2. Modern / outdated: memiliki model yang up to date / tidak ketinggalan jaman

3. Useful / not: dapat digunakan dengan baik/ bermanfaat

4. Popular/ unpopular: akrab di benak konsumen

5. Gentle / harsh: mempunyai tekstur produk halus / tidak kasar

6. Artificial / natural: keaslian komponen pendukung atau bentuk

Model konseptual dari citra merek menurut Keller (1993, p.63) meliputi atribut merek, keuntungan merek, dan sikap merek. Konsumen beranggapan bahwa citra sebuah perusahaan akan mempengaruhi citra merek suatu produk yang dihasilkannya. Citra merek dibangun dengan memperhatikan indicator-indikator seperti kualitas produk, harga, promosi, dan gaya hidup.

\subsubsection{Brand Experience}

Brand experience telah menarik perhatian dalam praktek pemasaran sekarang ini. Praktisi-praktisi pemasaran harus menyadari bahwa dengan memahami apa sebenarnya peran brand experience, akan sangat membantu para pemasar untuk mengembangkan strategi pemasaran. Menurut Brakus, Schmitt dan Zarantonello (2009). Brand Experience didefinisikan sebagai sensasi perasaan, kognisi dan tanggapan konsumen yang ditimbulkan oleh merek, terkait rangsangan yang ditimbulkan oleh desain merek, identitas merek, komunikasi pemasaran, orang dan lingkungan merek tersebut dipasarkan.

Menurut Brakus et al. (2009) Brand experience didefinisikan sebagai sensasi, perasaan, kognisi dan tanggapan konsumen yang ditimbulkan oleh merek, terkait rangsangan yang ditimbulkan oleh desain merek, identitas merek, komunikasi pemasaran, orang dan lingkungan merek tersebut dipasarkan. Untuk dapat mendefinisikan lebih jauh mengenai brand experience Brakus et al.(2009) memulai penelitian dengan melihat sudut pandang konsumen dengan menguji pengalamanpengalaman konsumen itu sendiri dan bagaimana pengalaman itu menghasilkan pendapat sikap, dan aspek lainnya dari perilaku konsumen. Brand experience dimulai pada saat konsumen mencari produk, membeli, menerima pelayanan dan mengkonsumsi produk. Brand experience dapat dirasakan secara langsung maupun secara tidak langsung saat konsumen melihat iklan atau juga saat pemasar mengkomunikasikan produk melalui website.

Menurut Brakus et al.(2009) terdapat 4 dimensi dalam mengukur brand experience :

1. Sensorik, menciptakan pengalaman melalui penglihatan, suara, sentuhan, bau, dan rasa.

2. Afeksi, pendekatan perasaan dengan mempengaruhi suasana hati, perasaan dan emosi.

3. Perilaku, menciptakan pengalaman secara fisik, pola perilaku, gaya hidup.

4. Intelektual, menciptakan pengalaman yang mendorong konsumen terlibat dalam pemikiran seksama mengenai keberadaan suatu merek.

Brand experience akan semakin berkesan apabila memiliki perbedaan dari kompetitor, dan disampaikan dengan jelas. Menurut Temporal (2001:64) bagi konsumen, brand experience yang baik lebih dari sekedar kualitas dan fungsi. Beberapa hal diantaranya adalah comments one gets from others, admiring looks "wow" expression, jealous stares, suggesstive glances, secreative smiles, dan "me too" faces.

\subsubsection{Brand Loyalty}

Brand loyalty, menurut Schiffman dan Kanuk (2009), dikatakan bahwa loyalitas merek adalah preferensi konsumen secara konsisten untuk melakukan pembelian pada merek yang sama pada produk yang spesifik atau kategori pelayanan tertentu. Loyalitas merek adalah sebuah komitmen yang kuat dalam berlangganan atau 
membeli suatu merek secara konsisten di masa yang akan datang. Dengan demikian masalah loyalitas merk ini sangatlah penting untuk mendapatkan perhatian dari sisi perusahaan, karena apabila perusahaan selama ini memiliki reputasi baik dibidang merk produk ataupun jasa yang disandangnya akan mendapatkan tempat tersendiri di hati konsumen dalam menentukan pilihan merk produk ataupun jasa yang akan mereka beli dan konsumsi dalam jangka panjang. Atau dengan perkataan lain apabila konsumen memiliki loyalitas yang tinggi pada suatu merk tertentu, maka konsumen akan senantiasa menggunakan merk tersebut secara konsisten terus menerus dalam jangka waktu yang panjang.

Menurut Lau dan Lee (1999), loyalitas terhadap merek adalah perilaku niat untuk membeli sebuah produk dan mendorong orang lain untuk melakukan hal yang sama. Tentu saja hal ini dapat memberikan imbalan yang besar bagi perusahaan terutama jika loyalitas ini bersifat jangka panjang dan kumulatif. Semakin lama loyalitas seorang pelanggan, semakin besar laba yang diperoleh perusahaan dari pelanggan tersebut. Konsumen kerap kali memberi produk lebih didasarkan pada mereknya baru kemudian kualitas yang ditawarkan oleh produk ataupun jasa (Aaker, 1996).

Menurut Aaker (2009) mendefinisikan loyalitas merek merupakan suatu ukuran keterkaitan pelanggan terhadap sebuah merek. Ukuran ini mampu memberikan gambaran tentang kemungkinan seorang pelanggan beralih ke produk lain terutama pada suatu merek tersebut didapatinya adanya perubahan, baik menyangkut harga atau atribut lain.

Rangkuti (2009) menjelaskan bahwa loyalitas merek dapat diukur melalui :

\section{Behavior measures}

Suatu cara langsung untuk menentukan loyalitas terutama untuk habitual behavior (perilaku kebiasaan) adalah dengan memperhitungkan pola pembelian aktual.

6. Measuring switch cost

Pengukuran pada variabel ini dapat mengidentifiksikan loyalitas pelanggan dalam suatu merek. Pada umumnya jika biaya untuk mengganti merek sangat mahal, pelanggan akan enggan untuk berganti merek sehingga laju penyusutan kelompok pelanggan dari waktu ke waktu akan rendah.

7. Measuring satisfaction

Pengukuran terhadap kepuasan atau ketidakpuasan pelanggan suatu merek merupakan indikator paling penting dalam loyalitas merek. Bila ketidakpuasan pelanggan terhadap suatu merek rendah, maka pada umumnya tidak cukup alasan bagi pelanggan untuk berpindah ke merek lain kecuali bila ada faktor penarik yang cukup kuat.

8. Measuring liking brand

Kesukaan terhadap merek, kepecayaan, perasaan hormat atau bersahabat dengan suatu merek membangkitkan kehangatan dan kedekatan dalam perasaan pelanggan. Akan sulit bagi merek lain untuk menarik pelanggan yang berada dalam tahap ini. Ukuran rasa suka tersebut adalah kemauan untuk membayar harga yang lebih mahal untuk mendapatkan produk tersebut.

9. Measuring commitment

Salah satu indikator kunci adalah jumlah interaksi dan komitmen pelanggan terkait dengan produk tersebut. Kesukaan pelanggan akan suatu merek akan mendorong mereka untuk membicarakan merek tersebut kepada orang lain baik dalam taraf menceritakan atau sampai tahap merekomendasikan. 


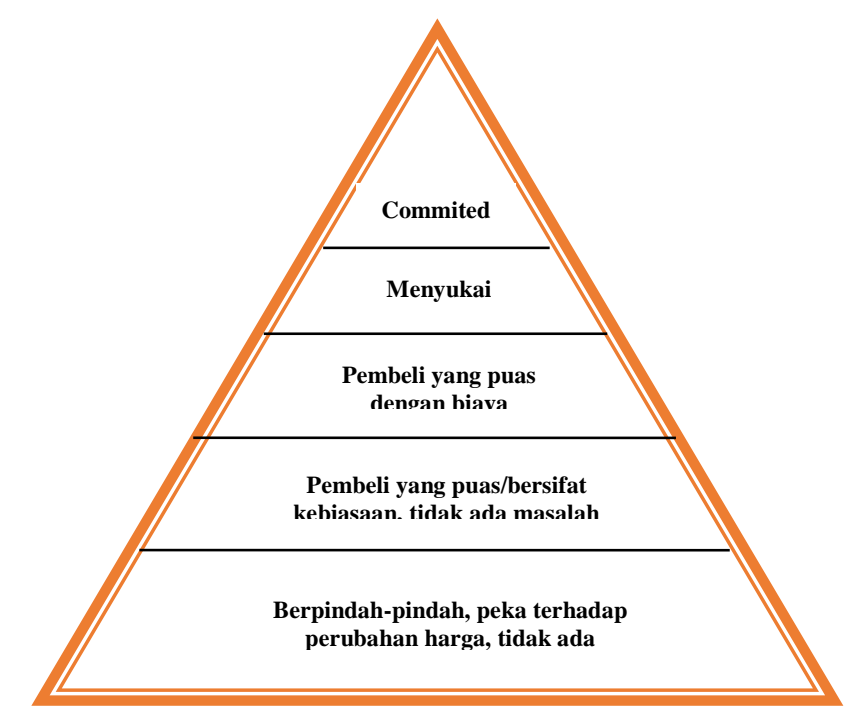

Sumber : Rangkuti, 2002

Gambar 1 Piramida Loyalitas Merk

\subsubsection{Kerangka Konseptual Penelitian Dan Hipotesis}

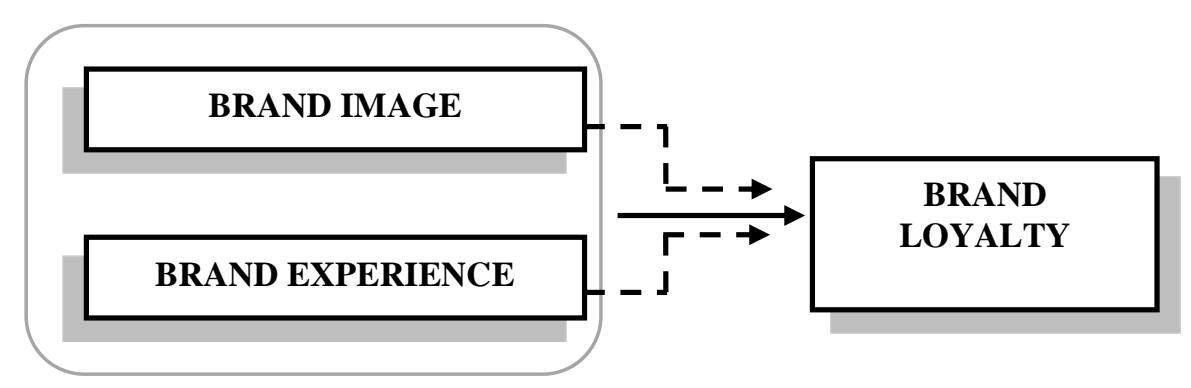

Gambar 2 Kerangka Konseptual Penelitian

Berdasarkan ilustrasi gambar 2 diatas, maka dapatlah penulis jelaskan bahwa kerangka konseptual penelitian ini menggambarkan pengaruh citra merk (brand image) dan pengalaman merk (brand experience) baik secara simultan maupun parsial terhadap loyalitas merk (brand loyalty).

Berdasarkan rumusan masalah, tujuan penelitian serta kerangka konseptual penelitian diatas, maka hipotesis yang penulis kemukakan dalam penelitian ini adalah :

1. Bahwa brand image dan brand experience berpengaruh secara simultan terhadap brand loyalty pada pengguna Kartu Brizzi Di BRI Unit Sentra Bisnis Driyorejo.

2. Bahwa brand image dan brand experience berpengaruh secara parsial terhadap brand loyalty pada pengguna Kartu Brizzi Di BRI Unit Sentra Bisnis Driyorejo.

\section{Metode Penelitian}

\subsection{Jenis Penelitian}

Dalam penelitian ini digunakan metode penelitian kuantitatif dengan pendekatan eksperimental. Penelitian eksperimental adalah penelitian dimana peneliti dengan sengaja membangkitkan timbulnya suatu kejadian atau keadaan dengan kata lain penelitian eksperimen adalah suatu cara untuk mencari hubungan sebab akibat ( casual effect) antara dua faktor yang sengaja ditimbulkan oleh peneliti dengan mengeliminasi atau mengurangi atau menyisihkan faktor-faktor lain yang bisa mengganggu. Eksperimen selalu dilakukan dengan maksud untuk melihat akibat dari suatu perlakuan yang dilakukan oleh peneliti. 


\subsection{Sampel Penelitian}

Populasi pada penelitian ini adalah seluruh pengguna kartu BRI Flazz (BRIZZI) yang berada di BRI Unit Sentra Bisnis Driyorejo. Karena jumlah konsumen ini tersebar dan sulit untuk diketahui secara pasti maka penentuan jumlah sampel yang akan digunakan dalam penelitian ini akan menggunakan rumus sebagaimana tertera di bawah ini :

$$
\begin{aligned}
& n=\frac{Z^{2}}{4(\text { moe })^{2}} \\
& \mathrm{n}=\text { jumlah sampel } \\
& \mathrm{Z} \quad=\text { tingkat keyakinan yang dalam penentuan sampel } 95 \%=1,96 \\
& \text { moe } \quad=\text { margin of error/kesalahan maksimum yang bisa ditoleransi, ditetapkan } \\
& \quad 10 \%
\end{aligned}
$$

Maka jumlah sampel yang diperoleh sebanyak :

$$
n=\frac{1,96^{2}}{4(0,1)^{2}}=96,04 \text { sampel }
$$

Berdasarkan rumus diatas sampel yang dapat diambil dari populasi yang besar sebanyak 96,04 orang. Berarti jumlah responden minimal adalah 97 orang, karena jumlah responden dibulatkan ke atas. Berdasar hal tersebut, maka peneliti mengambil sampel sebanyak 100 responden.

\subsection{Teknik Pengumpulan Data}

Metode pengumpulan data penelitian ini menggunakan :

\section{Kuesioner}

Kuesioner adalah metode pengumpulan data yang dilakukan dengan cara memberikan pertanyaanpertanyaan kepada responden dengan panduan kuesioner. Kuesioner dalam penelitian ini menggunakan pertanyaan dan tertutup.

2. Wawancara

Teknik pengumpulan data dengan cara tanya jawab antara peneliti dengan pengguna kartu BRI Flazz (BRIZZI) yang berada di BRI Unit Sentra Bisnis Driyorejo, wawancara ini dapat dilakukan secara langsung maupun tidak langsung.

3. Observasi

Observasi merupakan metode penelitian dimana peneliti melakukan pengamatan secara langsung pada obyek penelitian.

\section{Studi Pustaka}

Studi pustaka merupakan metode pengumpulan data yang dilakukan dengan membaca buku-buku, literatur, jurnal-jurnal, referensi yang berkaitan dengan penelitian ini dan penelitian terdahulu yang berkaitan dengan penelitian yang sedang dilakukan.

\subsection{Definisi Operasional Variabel}

Brand image (X1) yaitu pemahaman konsumen mengenai merek secara keseluruhan (Howard, 1994). Brand image memiliki tiga komponen, yaitu : karakteristik fisik produk suatu merek yang dikenali konsumen, kekuatan merek yang mampu menimbulkan manfaat yang disukai maupun tidak disukai berdasarkan skala penilaian konsumen, dan yang terakhir adalah kekuatan konsumen mengenai keyakinanya menentukan secara akurat kualitas suatu merek. Indikator yang digunakan untuk mengukur brand image, antara lain : friendly / unfriendly : kemudahan dikenali oleh konsumen (X1.1), modern / outdated : memiliki model yang up to date / tidak ketinggalan jaman (X1.2), useful / not : dapat digunakan dengan baik/ bermanfaat (X1.3), popular / unpopular : akrab di benak konsumen (X1.4) gentle / harsh : mempunyai tekstur produk halus / tidak kasar (X1.5), artificial / natural : keaslian komponen pendukung atau bentuk (X1.6)

Brand experience adalah didefinisikan sebagai sensasi, perasaan, kognisi dan tanggapan konsumen yang ditimbulkan oleh merek, terkait rangsangan yang ditimbulkan oleh desain merek, identitas merek, komunikasi pemasaran, orang dan lingkungan merek tersebut dipasarkan (Brakus et al.(2009). Indikator yang digunakan untuk mengukur brand experience, antara lain : 1) Sensorik, menciptakan pengalaman melalui penglihatan, suara, sentuhan, bau, dan rasa $(\mathrm{X} 2.1), 2) \quad$ Afeksi, pendekatan perasaan dengan mempengaruhi suasana hati, perasaan dan emosi (X2.2), 3) Perilaku, menciptakan pengalaman secara fisik, pola perilaku, gaya hidup (X2.3), dan 4) Intelektual, menciptakan pengalaman yang mendorong konsumen terlibat dalam pemikiran seksama mengenai keberadaan suatu merek (X2.4).

Loyalitas merek adalah preferensi konsumen secara konsisten untuk melakukan pembelian pada merek yang sama pada produk yang spesifik atau kategori pelayanan tertentu (Schiffman dan Kanuk, 2009). Indikator 
yang digunakan untuk mengukur loyalitas merk, antara lain : a. Behavior measures, b. Measuring switch cost, c. Measuring satisfaction, d. Measuring liking brand, e. Measuring commitment

\subsection{Teknik Analisis Data}

\section{Uji Reliabilitas}

Uji Reliabilitas merupakan alat untuk mengukur suatu kuisioner yang merupakan indikator dari variabel atau konstruk. Suatu kuisioner dikatakan reliable atau handal jika jawaban seseorang terhadap pertanyaan konsisten atau stabil dari waktu ke waktu.

$$
\begin{gathered}
\mathrm{A}=\frac{k \cdot r}{1+(k-1) r} \\
\text { Dimana }: \\
\alpha=\text { koefisien reliabilitas } \\
\mathrm{r}=\text { korelasi antar item } \\
\mathrm{k}=\text { jumlah item }
\end{gathered}
$$

2. 2. Uji Validitas

Uji validitas digunakan untuk mengukur sah atau tidaknya suatu kuesioner. Suatu kuesioner dikatakan sah jika pertanyaan pada kuesioner mampu mengungkapkan sesuatu yang akan diukur oleh kuesioner tersebut. Uji validitas dilakukan dengan membandingkan nilai $\mathrm{r}$ hitung (untuk setiap butir dapat dilihat pada kolom corrected item-total correlations) dengan $\mathrm{r}$ tabel untuk degree of freedom $(\mathrm{df})=\mathrm{n}-\mathrm{k}$, dalam hal ini $\mathrm{n}$ adalah jumlah sampel dan $\mathrm{k}$ adalah jumlah item. Jika $\mathrm{r}$ hitung $>\mathrm{r}$ tabel, maka pertanyaan tersebut dikatakan valid (Ghozali, $2005: 45$ )

\subsection{Uji Asumsi Klasik}

Untuk menguji apakah persamaan garis regresi yang diperoleh linier dan bisa dipergunakan untuk melakukan peramalan, maka harus dilakukan uji asumsi klasik yaitu :

1. Uji Multikolinearitas. Pengujian ini bertujuan untuk menguji apakah model regresi ditemukan adanya korelasi antar variabel bebas (independent). Model regresi yang baik seharusnya tidak tejadi korelasi diantara variabel independen. Jika variabel independen saling berkorelasi, maka variabel-variabel ini tidak ortogonal (variabel ortogonal adalah variabel independen yang nilai korelasi antar sesama variabel independen sama dengan nol).

2. Uji Normalitas. Uji normalitas bertujuan untuk menguji apakah dalam model regresi, variabel residual memiliki distribusi normal. Model regresi yang baik memiliki distribusi data yang normal atau mendekati normal. Pengujian normalitas dalam penelitian ini digunakan dengan melihat normal probability plot yang membandingkan distribusi kumulatif dari data sesungguhnya dengan distribusi kumulatif dari data normal. Sedangkan dasar pengambilan keputusan untuk uji normalitas data adalah (Ghozali, 2005):

3. Uji Heteroskedastisitas. Uji heteroskedastisitas bertujuan untuk menguji apakah dalam model regresi terjadi ketidaksamaan varian dari satu pengamatan ke pengamatan yang lain (Ghozali, 2005). Jika varian dari residual satu pengamatan ke pengamatan lain tetap, maka disebut homokedastisitas dan jika berbeda disebut heterokedastisitas. Model regresi yang baik adalah tidak terjadi heterokedastisitas (Ghozali, 2005). Cara mendeteksinya adalah dengan melihat ada tidaknya pola tertentu pada grafik (Ghozali, 2005).

\subsection{Analisa Regresi Berganda}

Dalam upaya menjawab permasalahan dalam penelitian ini maka digunakan analisis regresi linear berganda (Multiple Regression). Analisis regresi linear berganda digunakan untuk menganalisis pengaruh antara variabel independen (brand image, brand experience) terhadap variabel dependen yaitu brand loyalty. Rumus matematis dari regresi linear berganda yang umum digunakan dalam penelitian adalah sebagai berikut :

$$
\begin{aligned}
& \mathrm{Y}=\mathrm{a}+\mathrm{b} 1 \mathrm{x} 1+\mathrm{b} 2 \times 2+\mathrm{e} \\
& \text { Keterangan : } \\
& \mathrm{Y} \quad=\text { Brand loyalty } \\
& \mathrm{a}=\text { Konstanta } \\
& \mathrm{b}=\text { koefisien regresi } \\
& \mathrm{X}_{1} \quad=\text { Brand image } \\
& \mathrm{X}_{2} \quad=\text { Brand experience } \\
& \mathrm{e}=\text { Error }
\end{aligned}
$$




\subsection{Pengujian Hipotesis}

\subsubsection{Uji Simultan (Uji F) Dan Uji Parsial (Uji t)}

1. $\mathrm{Uji} \mathrm{F}$

Uji F digunakan untuk menguji hipotesis nol bahwa koefisien determinasi majemuk dalam populasi, $\mathrm{R}^{2}$, sama dengan nol. Uji signifikansi meliputi pengujian signifikansi persamaan regresi secara keseluruhan serta koefisien regresi parsial spesifik. Uji keseluruhan dapat dilakukan dengan menggunakan statistik F. Dalam penelitian ini Uji $\mathrm{F}$ digunakan untuk mempengaruhi variabel terkait, yaitu apakah variabel $\mathrm{X}_{1}, \mathrm{X}_{2}$, benar-benar berpengaruh secara bersama-sama terhadap variabel Y.

2. Uji t

Uji t pada dasarnya menunjukkan seberapa jauh pengaruh satu variabel independen secara individual dalam menerangkan variasi variabel independen (Ghozali, 2005). Hipotesis yang dipakai adalah :

\subsection{Koefisien Determinasi (Adjusted RSquare)}

Koefisien determinasi $\left(\mathrm{R}^{2}\right)$ pada intinya mengukur seberapa jauh kemampuan model (brand image dan brand experience) dalam menerangkan variasi variabel dependen/tidak bebas (brand loyalty). Nilai koefisien determinasi adalah antara nol (0) dan satu (1). Nilai $\mathrm{R}^{2}$ yang kecil berarti kemampuan variabel-variabel independen (bebas) dalam menjelaskan variasi-variabel dependen amat terbatas. Nilai yang mendekati satu berarti variabel-variabel independen memberikan hampir semua informasi yang dibutuhkan untuk memprediksi variasi variabel dependen.

\section{Hasil Penelitian Dan Pembahasan}

\subsection{Analisis Regresi Linier Berganda}

Tabel 1 Coefficients

\begin{tabular}{|c|c|c|c|c|c|c|c|c|c|c|c|}
\hline \multicolumn{12}{|c|}{ Coefficients $^{\mathrm{a}}$} \\
\hline & \multirow[t]{2}{*}{ Model } & \multicolumn{2}{|c|}{$\begin{array}{l}\text { Unstandardized } \\
\text { Coefficients }\end{array}$} & \multirow{2}{*}{$\begin{array}{c}\text { Standar } \\
\text { dized } \\
\text { Coeffici } \\
\text { ents } \\
\text { Beta }\end{array}$} & \multirow[t]{2}{*}{$\mathrm{t}$} & \multirow[t]{2}{*}{ Sig. } & \multicolumn{3}{|c|}{ Correlations } & \multicolumn{2}{|c|}{$\begin{array}{l}\text { Collinearity } \\
\text { Statistics }\end{array}$} \\
\hline & & B & $\begin{array}{l}\text { Std. } \\
\text { Error }\end{array}$ & & & & $\begin{array}{l}\text { Zero- } \\
\text { order }\end{array}$ & $\begin{array}{c}\text { Parti } \\
\text { al }\end{array}$ & Part & $\begin{array}{l}\text { Toler } \\
\text { ance }\end{array}$ & VIF \\
\hline 1 & (Constant) & 1.746 & .451 & & $\begin{array}{c}3.86 \\
8\end{array}$ & $\begin{array}{c}.00 \\
0\end{array}$ & & & & & \\
\hline & $\begin{array}{l}\text { Brand } \\
\text { Image }\end{array}$ & .526 & .104 & .463 & $\begin{array}{c}5.05 \\
5\end{array}$ & $\begin{array}{c}.00 \\
0\end{array}$ & .491 & .457 & .445 & .922 & 1.084 \\
\hline & $\begin{array}{c}\text { Brand } \\
\text { Experienc } \\
\mathrm{e}\end{array}$ & .099 & .091 & .099 & $\begin{array}{c}1.08 \\
6\end{array}$ & $\begin{array}{c}.28 \\
0\end{array}$ & .229 & .110 & .095 & .922 & 1.084 \\
\hline
\end{tabular}

\section{a. Dependent Variable: Brand Loyalty}

Sumber : Lampiran Hasil Pengolahan data. berikut :

Berdasarkan hasil perhitungan tersebut diatas, diperoleh persamaan regresi linier berganda sebagai

$$
Y=1.746+0.526 X_{1}+0.099 X_{2}+
$$

Interprestasi dari model regresi diatas adalah sebagai berikut :

1. Konstanta $\left(\beta_{0}\right)=1.746$ menunjukkan besarnya variabel brand loyalty yang tidak dipengaruhi oleh variabel brand image (X1), dan brand experience (X2), atau variabel bebas = 0 maka nilai brand loyalty sebesar 1.746.

2. Nilai koefisien brand image $\left(\beta_{1}\right)$ sebesar 0.526 menunjukkan bahwa jika variabel brand image $\left(\mathrm{X}_{1}\right)$ ditingkatkan, maka akan mengakibatkan peningkatan brand loyalty sebesar 0.526 dengan asumsi variabel lain konstan.

3. Nilai koefisien brand experience $\left(\beta_{2}\right)$ sebesar 0.099 menunjukkan bahwa jika variabel brand experience $\left(\mathrm{X}_{2}\right)$ ditingkatkan, maka akan mengakibatkan peningkatan brand loyalty sebesar 0.099, dengan asumsi variabel lain konstan.

4. $\mathrm{e}_{\mathrm{i}}$ menunjukkan faktor pengganggu di luar model yang diteliti. 


\subsection{Uji Asumsi Klasik}

\section{Uji Normalitas}

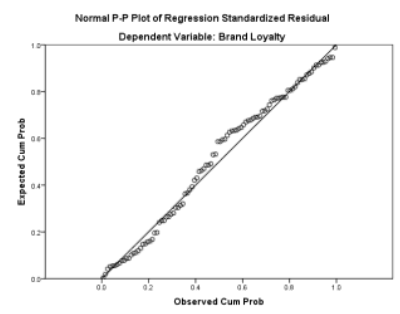

Gambar 3 Normal PP Plot

Berdasarkan gambar 3 Normal P-P Plot diatas, terlihat bahwa titik-titik tersebar mendekati garis diagonal, baik terletak diatas maupun dibawah garis maka dapat disimpulkan bahwa model ini berdistribusi normal. Maka asumsi normalitas terpenuhi.

2. Uji Multikolinieritas

\begin{tabular}{cc}
\multicolumn{2}{c}{ Tabel 2 Nilai Variance Inflation Variabel Bebas } \\
\hline Variabel & Nilai VIF \\
\hline Brand Image $\left(\mathrm{X}_{1}\right)$ & 1.084 \\
Brand Experience $\left(\mathrm{X}_{2}\right)$ & 1.084 \\
\hline
\end{tabular}

Sumber : Hasil analisis SPSS, data diolah penulis

Dan hasil perhitungan multikolinearitas dengan melihat nilai VIF, dapat ketahui bahwa untuk semua variabel mempunyai nilai VIF di bawah angka 10. Sehingga hasil uji multikolinearitas dengan menghitung matrik korelasi dan VIF menunjukkan tidak adanya multikolinearitas antar variabel bebas, karena nilai VIF dibawah angka 10.

3. Uji Heterokedastisitas

Berikut adalah gambar terjadi tidaknya heterokedastisitas :

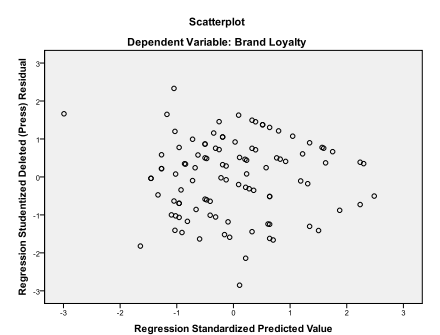

Gambar 4 Scatter Plot

Dari gambar 4 diketahui bahwa plot atau titik-titik tidak membentuk suatu pola tertentu sehingga dapat disimpulkan bahwa tidak terjadi heterokedastisitas.

\subsection{Analisis Koefisien Korelasi Dan Determinasi}

\section{Tabel 3 Model Summary}

Model Summary ${ }^{b}$

\begin{tabular}{|c|c|c|c|c|c|c|c|c|c|c|}
\hline \multirow{3}{*}{ Model } & \multirow{3}{*}{$\mathbf{R}$} & \multirow{3}{*}{$\begin{array}{c}\text { R } \\
\text { Squar } \\
\text { e }\end{array}$} & \multirow{3}{*}{$\begin{array}{l}\text { Adjusted } \\
\text { R Square }\end{array}$} & \multirow{3}{*}{$\begin{array}{l}\text { Std. Error } \\
\text { of the } \\
\text { Estimate }\end{array}$} & \multirow{2}{*}{\multicolumn{5}{|c|}{ Change Statistics }} & \multirow{3}{*}{$\begin{array}{l}\text { Durbin- } \\
\text { Watson }\end{array}$} \\
\hline & & & & & & & & & & \\
\hline & & & & & $\begin{array}{c}\text { R Square } \\
\text { Change }\end{array}$ & $\begin{array}{c}\text { F } \\
\text { Chang } \\
\text { e }\end{array}$ & df1 & df2 & $\begin{array}{c}\text { Sig. F } \\
\text { Change }\end{array}$ & \\
\hline 1 & $.500^{\mathrm{a}}$ & .250 & .234 & .55512 & .250 & 16.156 & , & 97 & .000 & 1.626 \\
\hline
\end{tabular}

a. Predictors: (Constant), Brand Experience, Brand Image

b. Dependent Variable: Brand Loyalty

Sumber : Lampiran Hasil Pengolahan data.

Nilai koefisien korelasi (R) menunjukkan seberapa erat pengaruh antara variabel bebas brand image $\left(\mathrm{X}_{1}\right)$, brand experience $\left(\mathrm{X}_{2}\right)$ dengan variabel tak bebas (brand loyalty), besarnya nilai koefisien korelasi adalah 0.500. Nilai tersebut menunjukkan bahwa pengaruh variabel brand image $\left(\mathrm{X}_{1}\right)$, brand experience $\left(\mathrm{X}_{2}\right)$, dengan variabel brand loyalty adalah mempunyai pengaruh yang cukup erat atau cukup kuat. 
Nilai koefisien determinasi atau $\mathrm{R}^{2}$ digunakan untuk mengukur seberapa jauh kemampuan model dalam menerangkan variasi variabel tak bebas (Y) yaitu variabel brand loyalty. Hasil dari perhitungan SPSS diperoleh nilai $\mathrm{R}^{2}=0.234$ yang berarti bahwa sebesar $23.4 \%$ variabel brand loyalty $(\mathrm{Y})$ dapat dijelaskan oleh variabel brand image $\left(\mathrm{X}_{1}\right)$, dan brand experience $\left(\mathrm{X}_{2}\right)$. Sedangkan sisanya $76.6 \%$ dipengaruhi oleh variabel lain diluar model yang diteliti.

\subsection{Pengujian Hipotesis}

a. Uji F ( Uji Simultan)

Uji serentak (uji F) menunjukkan bahwa seluruh variabel independen yang terdiri dari brand image (X1) dan brand experience (X2) berpengaruh secara nyata terhadap variabel dependen brand loyalty (Y).

Tabel 4 ANOVA

\begin{tabular}{llrrrrr}
\multicolumn{7}{c}{ ANOVA $^{\mathbf{b}}$} \\
\hline Model & & Sum of Squares & df & Mean Square & F & Sig. \\
\hline 1 & Regression & 9.957 & 2 & 4.978 & 16.156 \\
& Residual & 29.891 & 97 & .308 & & $.000^{\mathrm{a}}$ \\
& Total & 39.848 & 99 & & & \\
\hline
\end{tabular}

a. Predictors: (Constant), Brand Experience, Brand Image

b. Dependent Variable: Brand Loyalty

Langkah-langkah pengujian :

Sumber : Lampiran Hasil Pengolahan data.

1. Hipotesis

$\mathrm{H}_{0} \quad: \mathrm{b}_{1}=\mathrm{b}_{2}=0$ artinya variabel $\mathrm{X}_{1}, \mathrm{X}_{2}$, tidak memberikan pengaruh terhadap variabel terikat $(\mathrm{Y})$.

2. Besarnya nilai

$\mathrm{H}_{1} \quad: \mathrm{b}_{1} \neq \mathrm{b}_{2} \neq 0$ artinya variabel $\mathrm{X}_{1}, \mathrm{X}_{2}$, memberikan pengaruh terhadap variabel terikat (Y).

$\mathrm{F}$ tabel $=\mathrm{F}_{\alpha}(\mathrm{df}$ regresi, $\mathrm{df}$ residual $)=\mathrm{F}_{\alpha}(\mathrm{k}, \mathrm{n}-\mathrm{k}-1)$

$\mathrm{F}$ tabel $=\mathrm{F}_{0.05}(2,97)=3.09$

3. Daerah kritis atau daerah penolakan

Bila $\mathrm{F}$ hitung $\geq \mathrm{F}$ tabel maka $\mathrm{H}_{0}$ ditolak

Bila $\mathrm{F}$ hitung $<\mathrm{F}$ tabel maka $\mathrm{H}_{0}$ diterima

4. $\mathrm{F}_{\text {hitung }}=16.156$

5. Kesimpulan

Karena F hitung > F tabel yaitu $16.156>3.09$ atau dengan melihat besarnya significant level sebesar $0.000<0.05$, maka $\mathrm{H}_{0}$ ditolak pada tingkat signifikansi $5 \%$ sehingga dapat diambil kesimpulan bahwa semua variabel bebas brand image $\left(\mathrm{X}_{1}\right)$, dan brand experience $\left(\mathrm{X}_{2}\right)$ berpengaruh signifikan secara simultan terhadap variabel dependen brand loyalty $(\mathrm{Y})$. Dengan demikian hipotesis pertama yang menyatakan "Bahwa brand image dan brand experience berpengaruh secara simultan terhadap brand loyalty pada pengguna Kartu Brizzi Di BRI Unit Sentra Bisnis Driyorejo" terbukti kebenarannya secara empiris.

\section{b. Uji t (Uji Parsial)}

Untuk menguji hipotesis digunakan uji t yang menunjukkan pengaruh secara parsial dari masing-masing variabel bebas terhadap variabel terikat (tak bebas). Pada tahapan ini dilakukan pengujian terhadap pengaruh variabel bebas yang terdapat pada model yang terbentuk untuk mengetahui apakah variabel bebas (X) yang ada dalam model secara parsial mempunyai pengaruh yang signifikan terhadap variabel terikat (Y).

Tabel 5 Coefficients

Coefficients $^{\mathrm{a}}$

\begin{tabular}{|c|c|c|c|c|c|c|c|c|c|c|c|}
\hline \multicolumn{2}{|c|}{ Model } & \multicolumn{2}{|c|}{$\begin{array}{l}\text { Unstandardized } \\
\text { Coefficients }\end{array}$} & \multirow{2}{*}{$\begin{array}{c}\text { Standard } \\
\text { ized } \\
\text { Coefficie } \\
\text { nts } \\
\text { Beta }\end{array}$} & \multirow[t]{2}{*}{$t$} & \multirow[t]{2}{*}{ Sig. } & \multicolumn{3}{|c|}{ Correlations } & \multicolumn{2}{|c|}{$\begin{array}{l}\text { Collinearity } \\
\text { Statistics }\end{array}$} \\
\hline & & B & $\begin{array}{l}\text { Std. } \\
\text { Error }\end{array}$ & & & & $\begin{array}{l}\text { Zero- } \\
\text { order }\end{array}$ & $\begin{array}{l}\text { Parti } \\
\text { al }\end{array}$ & Part & $\begin{array}{c}\text { Tolera } \\
\text { nce }\end{array}$ & VIF \\
\hline \multirow[t]{3}{*}{1} & (Constant) & 1.746 & .451 & & 3.868 & .000 & & & & & \\
\hline & Brand Image & .526 & .104 & .463 & 5.055 & .000 & .491 & .457 & .445 & .922 & 1.084 \\
\hline & $\begin{array}{l}\text { Brand } \\
\text { Experience }\end{array}$ & .099 & .091 & .099 & 1.086 & .280 & .229 & .110 & .095 & .922 & 1.084 \\
\hline
\end{tabular}

Sumber : Lampiran Hasil Pengolahan data. 
c. Uji Parsial Antara Variabel brand image $\left(\mathrm{X}_{1}\right)$ Terhadap Variabel brand loyalty $(\mathrm{Y})$

Untuk menguji hipotesis digunakan uji t yang menunjukkan pengaruh secara parsial variabel brand image $(\mathrm{X} 1)$ terhadap variabel brand loyalty $(\mathrm{Y})$. Hipotesis :

a. $\mathrm{H}_{0}: \beta_{1}=0$ (Artinya, variabel brand image $\left(\mathrm{X}_{1}\right)$ tidak mempunyai pengaruh yang signifikan terhadap variabel brand loyalty)

b. $\mathrm{H}_{1}: \beta_{1} \neq 0$ (Artinya, variabel brand image $\left(\mathrm{X}_{1}\right)$ mempunyai pengaruh yang signifikan terhadap variabel brand loyalty)

c. $\quad \alpha=0,05$ dengan df $(\mathrm{n}-\mathrm{k}-1)=97$ dimana $\mathrm{t}_{\text {tabel }}=1.661$

d. $t_{\text {hitung }}=5.055$

e. Kesimpulan :

Berdasarkan output SPSS versi 18.00 diperoleh $t_{\text {hitung }}$ sebesar 5.055 lebih besar dari $\mathrm{t}_{\text {tabel }}$ sebesar 1.661 atau significant level sebesar $0.000<0.05$, maka $\mathrm{H}_{0}$ ditolak pada tingkat signifikansi $5 \%$ sehingga kesimpulannya secara parsial variabel brand image $\left(\mathrm{X}_{1}\right)$ berpengaruh signifikan terhadap brand loyalty $(\mathrm{Y})$.

\subsection{Uji Parsial Antara Variabel brand experience $\left(\mathrm{X}_{2}\right)$ Terhadap Variabel brand loyalty $(\mathrm{Y})$}

Untuk menguji hipotesis digunakan uji t yang menunjukkan pengaruh secara parsial variabel brand experience $\left(\mathrm{X}_{2}\right)$ terhadap variabel brand loyalty $(\mathrm{Y})$.

Hipotesis :

a. $\mathrm{H}_{0}: \beta_{2}=0$ (Artinya, variabel brand experience $\left(\mathrm{X}_{2}\right)$ tidak mempunyai pengaruh yang signifikan terhadap variabel brand loyalty)

b. $\mathrm{H}_{1}: \beta_{2} \neq 0$ (Artinya, variabel brand experience $\left(\mathrm{X}_{2}\right)$ mempunyai pengaruh yang signifikan terhadap variabel brand loyalty)

c. $\quad \alpha=0,05$ dengan $\mathrm{df}(\mathrm{n}-\mathrm{k}-1)=97$ dimana $\mathrm{t}_{\text {tabel }}=1.661$

d. $t_{\text {hitung }}=1.086$

e. Kesimpulan :

Berdasarkan output SPSS versi 18.00 diperoleh $t_{\text {hitung }}$ sebesar 1.086 lebih kecil dari $t_{\text {tabel }}$ sebesar 1.661 atau significant level sebesar $0.280>0.05$ maka $\mathrm{H}_{0}$ diterima pada tingkat signifikansi $5 \%$ sehingga kesimpulannya secara parsial variabel brand experience $\left(\mathrm{X}_{2}\right)$ tidak berpengaruh signifikan terhadap brand loyalty ( Y ).

Dengan demikian dapatlah penulis simpulkan bahwa hipotesis kedua yang menyatakan "Bahwa Brand image dan brand experience berpengaruh secara parsial dan signifikan terhadap brand loyalty pada pengguna Kartu Brizzi Di BRI Unit Sentra Bisnis Driyorejo" kurang terbukti kebenarannya secara empiris. Hal ini disebabkan karena dari dua (2) variabel bebas yang ada hanya variabel brand image yang mempunyai pengaruh signifikan terhadap brand loyalty, sedangkan variabel brand experience tidak mempunyai pengaruh signifikan terhadap brand loyalty.

\subsection{Variabel Dominan}

Nilai thitung parsial menunjukkan seberapa erat hubungan atau pengaruh antara variabel bebas yang meliputi variabel brand image $\left(\mathrm{X}_{1}\right)$, dan brand experience $\left(\mathrm{X}_{2}\right)$ secara parsial mempunyai pengaruh yang signifikan terhadap variabel terikat brand loyalty $(\mathrm{Y})$.

Tabel 6

Nilai t hitung Varibel Bebas

\begin{tabular}{ccc}
\hline Variable & $\mathrm{t}_{\text {hitung }}$ & sig \\
\hline Brand Image $\left(\mathrm{X}_{1}\right)$ & 5.055 & 0.000 \\
Brand Experience $\left(\mathrm{X}_{2}\right)$ & 1.086 & 0.280 \\
\hline
\end{tabular}

Sumber: Lampiran 7, Data Diolah

Berdasarkan data yang didapat dilihat pada Tabel 4.18 di atas, terlihat bahwa nilai t hitung terbesar adalah untuk variabel brand image $\left(\mathrm{X}_{1}\right)$ sebesar 5.055, artinya secara parsial variabel brand image $\left(\mathrm{X}_{1}\right)$ memberikan pengaruh yang paling besar atau dominan terhadap brand loyalty.

\subsection{Pembahasan Hasil Penelitian}

Berdasarkan hasil perhitungan dengan analisis regresi linear berganda diperoleh persamaan regresi model di bawah ini:

$$
\mathrm{Y}=1.746+0.526 \mathrm{X}_{1}+0.099 \mathrm{X}_{2}+\mathrm{e}
$$

Besarnya nilai e dapat dicari dengan menggunakan formulasi sebagaimana nerikut ini : $\mathrm{e}=$ Stand Error of the Estimate $(\mathrm{SEE}) \mathrm{x}_{\mathrm{tabel}}$ 


$$
\begin{aligned}
& =.55512 \times 1.661 \\
& =0.922
\end{aligned}
$$

Dengan demikian persamaan regresinya menjadi :

$$
Y=1.746+0.526 X_{1}+0.099 X_{2}+
$$

Dari nilai perolehan persamaan regresi model diketahui bahwa variabel brand image $\left(\mathrm{X}_{1}\right)$ dan brand experience $\left(\mathrm{X}_{2}\right)$ menunjukkan nilai koefisien regresi positif, hal tersebut menunjukkan adanya arah positif atau hubungan searah dari variabel brand image $\left(\mathrm{X}_{1}\right)$, brand experience $\left(\mathrm{X}_{2}\right)$ terhadap brand loyalty. Hal ini dapat diartikan bahwa jika semakin meningkat brand image dan brand experience maka brand loyalty akan semakin meningkat pula, begitu pula sebaliknya jika semakin menurun brand image dan brand experience maka brand loyalty akan semakin menurun.

Hasil analisis menunjukkan bahwa brand image $\left(\mathrm{X}_{1}\right)$, brand experience $\left(\mathrm{X}_{2}\right)$ secara simultan (bersamasama) berpengaruh signifikan terhadap brand loyalty (Y). Hal ini diketahui dari hasil uji $\mathrm{F}$ yang menunjukkan bahwa nilai F hitung > F tabel yaitu $16.156>3.09$ dan dengan probabilitas kesalahan model yang diuji adalah 0,000 yang berarti probabilitas lebih kecil dari tingkat signifikansi 0,05 , sehingga pengaruh seluruh variabel independen (brand image dan brand experience) terhadap variabel dependennya (brand loyalty) adalah bermakna. Dengan demikian hipotesis pertama penelitian yang berbunyi "Bahwa brand image dan brand experience berpengaruh secara simultan terhadap brand loyalty pada pengguna Kartu Brizzi Di BRI Unit Sentra Bisnis Driyorejo" terbukti kebenarannya secara empiris.

Seluruh variabel independen atau variabel bebas berpengaruh atau dapat menjelaskan variasi dari variabel terikat sebesar 23.4\%. Hal ini dibuktikan dengan melihat nilai koefisien determinasi (Adjusted $R$ Square) sebesar 0.234 dari hasil analisis regresi linier berganda menggunakan program statistik SPSS seperti dalam Lampiran 3, sedangkan sisanya yaitu 76.6\% adalah dipengaruhi oleh variabel lain di luar model. Adapun variabel-variabel lain yang kemungkinan dapat mempengaruhi brand loyalty selain brand image dan brand experience, berkaitan dengan penelitian yang penulis lakukan ini, menurut hemat penulis antara lain : brand trust, brand equity, brand identity, brand reputation, brand satisfaction. Dengan demikian, kalau dilakukan penelitian lanjutan dengan memasukkan variabel-variabel yang penulis sebutkan diatas sebagai variabel bebas, menurut hemat penulis akan bisa meningkatkan kontribusi variabel bebas dalam mempengaruhi variabel terikatnya atau dengan perkataan lain kontribusi variabel bebas dalam mempengaruhi variabel terikat akan semakin mendekati $100 \%$.

Angka koefisien korelasi (R) menunjukkan hubungan keterikatan antara variabel bebas brand image dan brand experience secara bersama-sama dengan brand loyalty (Y) yang cukup kuat atau cukup erat, karena menunjukkan angka sebesar 0.500 .

Hasil penelitian juga menunjukkan bahwa brand image secara parsial berpengaruh signifikan terhadap brand loyalty. Hal ini berarti bahwa semakin menarik citra (image) suatu merk produk berupa barang atau jasa tertentu akan semakin loyal seseorang pada merk daripada produk tersebut. Sedangkan variabel brand experience secara parsial tidak berpengaruh signifikan terhadap brand loyalty. Berdasarkan hasil wawancara penulis dengan responden selama penelitian, beberapa responden pernah mengalami pengalaman yang kurang menyenangkan sewaktu mereka memiliki dan menggunakan kartu BRIZZI, pengalaman yang telah dialami tersebut pada dasarnya akan membentuk dan mempengaruhi sikap seseorang konsumen atau pelanggan dalam bertindak atau dalam hal ini adalah menggunakan kartu BRIZZI untuk keperluan transaksi. Dengan demikian persepsi responden terhadap brand image dan brand experience pada dasarnya menunjukkan sampai seberapa besar seorang konsumen atau pelanggan memandang merk produk sangat menarik berkaitan dengan kualitas barangnya, daya tahannya, keunikannya, kharakteristiknya, harganya, serta seberapa banyak seseorang memiliki pengalaman yang menarik dan menyenangkan terhadap suatu merk produk tertentu yang akan sangat mempengaruhi konsumen menjadi loyal terhadap merk produk tersebut.

Hal ini bisa dilihat dari rata-rata jawaban responden atas indicator pada brand image sebesar 3.70 yang menunjukkan bahwa pemilik atau pengguna kartu BRIZZI setuju dengan semua item pernyataan yang ada dalam kuesioner. Rata-rata jawaban responden atas indicator dalam brand experience sebesar 3.97, yang berarti bahwa pemilik atau pengguna kartu BRIZZI setuju dengan semua item pernyataan yang ada dalam kuesioner. Dan Rata-rata jawaban responden atas indicator dalam brand loyalty sebesar 4.08, yang berarti bahwa pemilik atau pengguna kartu BRIZZI setuju dengan semua item pernyataan yang ada dalam kuesioner.

Masalah loyalitas pelanggan dalam studi pemasaran sangat berperan penting bagi kehidupan jangka panjang perusahaan. Oleh karenanya, yang menjadi pertimbangan utama bagi pemasar dalam memasarkan produknya ke pasar, hendaknya bisa melihat bagaimana pandangan para pelanggan terhadap citra merk dari produk perusahaan serta apakah selama menggunakan produk, pelanggan memiliki pengalaman-pengalaman yang sngat menyenangkan dalam penggunaan produknya. 
Oleh karenanya, tantangan terbesar sekarang ini dan dimasa-masa mendatang dalam memasarkan produknya adalah bagaimana dapat meng-create suatu strategi branding yang tepat di era persaingan yang semakin kompetitif serta munculnya para pesaing baru di pasar.

Dengan perkataan lain, masalah brand loyalty menjadi hal yang sangat penting untuk selalu ditumbuhkembangkan pada sisi pelanggan, agar pelanggan selalu dan selalu mempertimbangkan merk produk perusahaan manakala dia dihadapkan pada salah satu kebutuhan akan produk atau jasa tertentu.

\section{Penutup \\ 4.1 Kesimpulan}

Berdasarkan uraian pada bab-bab sebelumnya, maka kesimpulan yang diperoleh dari hasil penelitian ini :

1. Berdasarkan uji secara simultan (uji F), maka seluruh variabel penelitian yang terdiri dari brand image dan brand experience berpengaruh signifikan terhadap variabel brand loyalty. Hal ini dibuktikan secara empiris dari perhitungan SPSS yang menghasilkan nilai F hitung > F tabel yaitu 16.156 > 3.09 atau dengan melihat besarnya significant level sebesar $0.000<0.05$. Dengan demikian hipotesis pertama yang penulis kemukakan dalam penelitian ini secara empiris terbukti kebenarannya.

2. Berdasarkan uji secara parsial (uji t), variabel brand image berpengaruh signifikan terhadap brand loyalty. Hal ini dibuktikan secara empiris dari perhitungan SPSS yang menghasilkan nilai $t$ hitung $>\mathrm{t}$ tabel yaitu $5.055>1.661$ atau dengan melihat besarnya significant level sebesar $0.000<0.05$. Sedangkan variabel brand experience tidak berpengaruh signifikan terhadap brand loyalty. Hal ini dibuktikan secara empiris dari perhitungan SPSS yang menghasilkan nilai t hitung < t tabel yaitu $1.086<1.661$ atau dengan melihat besarnya significant level sebesar $0.280>0.05$. Dengan demikian hipotesis kedua yang penulis kemukakan dalam penelitian ini secara empiris kurang terbukti kebenarannya.

3. Hasil penelitian juga menunjukka bahwa variabel brand image merupakan variabel dominan yang mempengaruhi brand loyalty dibandingkan dengan variabel brand experience.

\subsection{Saran}

Saran yang diajukan dalam penelitian ini diantaranya adalah sebagai berikut :

1. Hendaknya manajemen PT. Bank Rakyat Indonesia (Persero) senantiasa mempromosikan kegunaan kartu BRIZZI pada masyarakat yang memiliki dan menggunakan dalam setiap kegiatan transaksi keuangan, sehingga hal ini tentunya akan semakin meningkatkan citra (image) kartu BRIZZI dibandingkan dengan kartu elektronik dari perbankan lainnya. Dan yang tidak kalah pentingnya adalah manajemen PT. Bank Rakyat Indonesia (Persero) senantiasa juga selalu mengedukasi pada para pengguna maupun masyarakat luas mengenai pentingnya memiliki kartu elektronik e-money untuk kemudahan dalam setiap bertransaksi.

2. Hendaknya manajemen bank PT. Bank Rakyat Indonesia (Persero) dapat lebih memperhatikan pada masalah-masalah yang menyebabkan para pemilik atau pengguna kartu BRIZZI memiliki pengalaman yang kurang menyenangkan selama mereka menggunakan kartunya untuk setiap kegiatan transaksi keuangan, misalnya kemudahan bagi setiap pemilik atau pengguna kartu BRIZZI manakala bertransaksi dimanapun dan untuk kegunaan apapun. Hal ini berarti para pemilik atau pengguna kartu BRIZZI menghendaki bahwa kartu BRIZZI bisa dpergunakan untuk transaksi pembayaran apapun di setiap merchant manakala mereka melakukan transaksi pembayaran

3. Kontribusi variabel bebas dalam mempengaruhi variabel terikat dalam penelitian ini masih menunjukkan nilai yang relative kecil, oleh karenanya hasil penelitian ini akan dapat dijadikan sebagai referensi bagi peneliti yang lain untuk melakukan penelitian lanjutan dengan menambahkan variabel bebas penelitian, antara lain : brand trust, brand reputation, brand identity, brand equity dan lain-lainnya yang berkaitan dengan masalah branding strategy dalam pemasaran.

\section{DAFTAR PUSTAKA}

Aaker David A, 1991, "Managing Brand Equity, Capitalizing on the Value of a Brand Name", The Free Press,New York.

-------, 1989, “Competitive Advantage of the Firm”, Journal of Strategic Research, New York.

-------, 1996, "Building Strong Brands" 1st ed, The Free Press: New York.

-------, and Kevin L, Keller, 1990, 'Consumer Evaluations of Brand Extension”, Journal of Marketing, 54 (January), 27-41.

Brakus, J.J., Schmitt, B.H. and Zarantonello, L. 2009. Brand Experience: What is it? How is it Measured? Does it Affect Loyalty?. Journal of Marketing, 73(3), pp: 52-68.

Basu Swastha Dharmmesta, 1999, "Loyalitas pelanggan: Sebuah Kajian Konseptual Sebagai Panduan Bagi Peneliti”, Jurnal Ekonomi dan Bisnis Indonesia, No,3:73- 88Vol, 14, BPFE-UGM.

Darsono, Licen Indahwati (2005), "Loyalty \& Disloyalty: Sebuah Pandangan Komprehensif Dalam Analisis Loyalitas Pelanggan,” Jurnal Administrasi dan Bisnis, Vol.4 
Durianto, D., Sugiarto, \& Tony, S. (2001). Strategi Menaklukan Pasar Melalui Riset Ekuitas dan Perilaku Merek. Jakarta: Gramedia.

Ferrinadewi, Erna 2008, Merek dan Psikologi Konsumen, Implikasi pada Strategi Pemasaran, Graha Ilmu, Yogyakarta.

Fournier, S. (1998), "Consumers and their brands: developing relationship theory in consumer research", Journal of Consumer Marketing, Vol. 24 No. 4, pp. 343-74.

Ferdinand, Augusty T., 2000, “Manajemen Pemasaran : Sebuah Pendekatan Strategik “, Research Paper Series, Program Magister Manajemen, Universitas Diponegoro, Semarang

Freddy , Rangkuti. (2002) Strategi Promosi Yang Kreatif \& Analisis Kasus Integrated Marketing Communication. Jakarta : Penerbit Gramedia Pustaka Utama.

Griffin, Jill, 1995, Customer Loyalty: How to earn it, How to keep it, USA: A Division Of Simon and Schukers Inc.

Graeff, T,R, 1996, "Using promotional messages to manage the effects of brand and self image on brands evaluation", Journal of Consumer Marketing, Vol,13, No,3, pp 4-18

Haubl, G, "A cross-national investigation of the effects of country of origin and brand name on the evaluation of a new car,” International Marketing Review, Vol, 13 No, 5, pp, 76-97.

Keller, K.L. (2003). Strategic Brand Management: Building, Measuring, and Managing Brand Equity. 2nd ed. New Jersey: Prentice-Hall, Inc.

Knapp, D. E, 2000. The Brand Mindset, USA : Mc.Graw-Hill.

Kotler, P. (2003). Marketing Management. 11th ed. New Jersey: Pearson Education, Inc.

Kotler, Philip, and Amstrong Gary, (1996). Principles of marketing, (9nd) ed, Englewood Cliffs, New Jersey: Prentice Hall Int, Inc.

Low and Lamb , 2000, "The measurement and dimensionality of brand associations", The Journal of Product and Brand Management, Santa Barbara: 2000, Vol, 9, Iss, 6;pg, 350

Murphy, J,M, (1990)," Brand Strategy”, Prentice-Hall, Englewood Cliffs, NJ,

Olson, Peter, 1993, Consumer Behavior and Marketing Strategy, Richard D. Irwan Inc, Boston, Third Edition.

Park, W.C. and Srinivasan, V. (1994), “A survey-based method for measuring and

understanding brand equity and its extendibility”, Journal of Marketing Research, Vol. 31 No. 2, pp. 271 -88.

Rizan, M., Basrah, S., \& Yusiyana, S. (2012). Pengaruh Brand image dan Brand trust Terhadap Brand loyalty The Botol Sosro. Jurnal Riset Manajemen Sains Indonesia.

Schiffman, Leon G and Kanuk, Leslie L (2007) Customer Behavior. 8th Edition. Pearson Prentice Hall, New Jersey.

Selnes, Fred (1993), “An Examination of the Effect of Product Performance on Brand Reputation, Satisfaction and Loyalty," European Journal of Marketing, Vol.27, No 9

Simamora, B. 2006, Aura Merk : 7 Langkah Membangun Merk Yang Kuat, Edisi Pertama, Penerbit Gramedia Pustaka, Jakarta

Sugiyono. 2007. Metode Penelitian Pendidikan: Pendekatan Kuantitatif, Kualitatif dan R\&D. Bandung: Alfabeta.

Tjiptono, Fandy.(2008). Strategi Pemasaran. Edisi ke tiga. Yogyakarta: Andi.

Urde, M.,1999, “ Brand Orientation A Mindset into Strategic Resources: Journal of Consumer Research Vol 16 March pp

Yasin.MM and Yavas U, 1999, "Enhancing Customer Orientation Service Delivery Systems an Integrative Framework", Managing Service Quality Vol 9 No 3

Zeithaml, Valerie, Parasuraman A.A. \& Leonard, Berry L., (1990). Delivering quality service: balancing customer perseption \& expectation. Ney York.

Zeithaml, V.A., and Bitner, M.J., (2003). Services marketing: integrating customer focus across the firm, (International Edition), New York: The McGraw-Hill Companies. Inc.

Zeithaml, Valerie A, Bitner, Mary J, Gremler, Dwyne D. (2006). Integrating Customer Focus Across The Firm (4th ed). New York: The McGraw-Hill Companies, Inc. 